\title{
Web-Based Synchronous Speaking Platforms: Students' Attitudes and Practices
}

\author{
Abdurrazzag Alghammas ${ }^{1}$ \\ ${ }^{1}$ Department of English Language and Translation, College of Arabic and Social Studies, Qassim University, \\ Saudi Arabia \\ Correspondence: Abdurrazzag Alghammas, Department of English Language and Translation, College of Arabic \\ and Social Studies, Qassim University, Saudi Arabia. E-mail: alghammas@qu.edu.sa
}

Received: January 8, 2020 Accepted: February 20, 2020 Online Published: March 11, 2020

doi:10.5539/ijel.v10n3p21 URL: https://doi.org/10.5539/ijel.v10n3p21

\begin{abstract}
This study employed the interaction hypothesis (Long, 1983) to investigate attitudes towards different English accents (i.e., American and British) of 40 male undergraduate EFL students majoring in English. It explored the reasons for such views, as well as identifying the accent the participants found most effective for communication. The study also examined students' attitudes to online speaking by means of a Synchronous Computer-Mediated Communication (SCMC) website known as 'Cambly'. Students were granted free access to the Cambly website for live interaction with Native English Speakers (NES). Each student talked for 15 minutes with an American and British interlocutor, enabling the researcher to recognize the common topics appearing within these conversations. Data were collected using a mixed-method approach, employing a web-based survey of closed and open-ended questions, alongside the recorded conversations. The key findings reveal that students enjoyed the SCMC conversation and also found it beneficial for improving their speaking skills. Furthermore, SCMC allowed students to choose the topic and negotiate meaning with native speakers during a lengthy conversation. This study establishes that students preferred American to British accents and felt more confident in understanding American speakers. The study concludes by highlighting the practical implications for teaching speaking skills, also suggesting new directions for future research.
\end{abstract}

Keywords: practices in synchronous computer-mediated communication, attitudes towards English accent, topics of conversation

\section{Introduction}

As a productive skill, speaking demands considerable practice in daily conversational settings, requiring learners to express ideas and negotiate meaning in authentic situations. However, within the EFL context, there are limited opportunities for Arab students to undertake natural interaction in English, or routinely converse with Native English Speakers (NES) (Bilbatua, Saito, \& Bissoonauth-Bedford, 2012; Tsukamoto, Nuspliger, \& Senzaki, 2009). This results in many Arab students becoming demotivated and lacking the speaking skills enabling them to express themselves openly (Alrabai, 2014; Alrashidi \& Phan, 2015; Al-Seghayer, 2014; Hamad, 2013; Mahboob \& Elyas, 2014). Internet-based applications have now opened new avenues to facilitate language learners to improve their conversational skills. These are known as Computer-Mediated Communication (CMC) tools and give opportunities for easy and convenient communication with native speakers, either synchronously or asynchronously. CMC creates situations in which language learners locate native (and native-like) English speakers with whom to engage in discussion, without necessarily involving direct learning (Beatty, 2003). Speaking is spontaneous in nature, and language learners are required to practice speaking in authentic situations outside the limitations of the classroom. This is encouraged by synchronous CMC tools, which allow such communication without any time restrictions. Due to speaking being a social act, almost all studies are theoretically framed by Long's Interaction Hypothesis and Vygotskian's Sociocultural Theory (Lin, 2014).

\section{Literature Review}

A number of studies have examined the use of SCMC in language learning and teaching following the arrival of communication technologies, which promote social networking and collaboration. Ziegler (2016) undertook a meta-analysis study focusing on empirical research into the impact of SCMC on L2 learning outcomes, including measures of production, performance, and development. In addition, several studies have investigated the 
affordances of SCMC in language learning in general, and speaking skills in particular, when tackling different topics related to communication and interaction using different CMC modalities. The correlation between SCMC and the development of speaking skills has been the main focus of researchers since the advent of CMC (Chang, 2007; Fernández-Garcia \& Martínez-Arbelaiz, 2002; Lai \& Zhao, 2006; Satar \& Özdener, 2008).

Volle (2005) conducted a study on 19 Spanish learners following an online distance education course examining oral development in two types of recorded speaking activities. During one semester, the students created 2 recorded emails each week, as well as having synchronous conversations with their instructor via MSN messenger. The researcher noted significant gains in oral proficiency between the beginning and end of the semester. Similarly, Satar and Özdener (2008) investigated the use of 2 SCMC tools (i.e., text and chat) on learners of English attending a vocational high school. 90 students were divided into 3 groups, 2 experimental, who used both text and chat, and one control. Over a 4-week period, the experimental groups engaged in 45 minutes of chat guided by 8 separate tasks. The researchers noted a remarkable increase in language use in both the text and chat experimental groups in comparison to the control.

A further commonly explored topic concerns a comparison between SCMC and face to face (F2F) interaction (Blake, Wilson, Cetto, \& Pardo-Ballester, 2008; Warschauer, 1996; Ziegler, 2016). However, this has revealed contradictory findings concerning the impact of SCMC and F2F on interaction. While many empirical studies have confirmed the efficacy of SCMC when it comes to interaction (Abrams, 2003; AbuSeileek, 2007; Blake, 2009; Huang \& Hung, 2010; Lord, 2008; Payne \& Whitney, 2002), a number have disagreed (e.g., Blake et al., 2008; Chang, 2007; Loewen \& Erlam, 2006; Sanders, 2005; Sun, 2012).

A considerable degree of research has reported students' positive attitude towards SCMC in language classes. Sun (2012) utilized the use of educational voice blogs with 46 Taiwanese college students learning English as a foreign language, examining the perceived improvement gained from such extensive practice on speaking performance. Over a period of 18 weeks, the students posted voice blogs on a class blog to supplement the insufficient availability of speaking practice inside the classroom. The students' outcomes were collected by means of a questionnaire, demonstrating the perceived gains in their speaking proficiency. In addition, Terhune (2016) undertook research over 12 weeks on 20 Japanese students taking an advanced English class in a department of international communication. He examined the use of Skype with teachers communicating with students who had not previously used CMC for language learning. Although the students failed to use this experience to its full potential, they rated it highly.

Interaction with NES is easily achievable with different SCMC applications. In the context of EFL, a number of researchers have examined the impact of chatting with native speakers on students' language proficiency (e.g., Satar \& Ozdener, 2008; Urun, 2016). An example from the Arab world is the implementation of synchronous forms of communication (video and chat) by Mahfouz and Ihmeideh (2009), who investigated the attitudes of 320 Jordanian university students towards chatting with NES in order to improve their language skills. The results revealed that students' productive skills (i.e., speaking) were higher than their receptive skills (i.e., listening and reading). However, a significant difference was identified between students' achievements in relation to gender, faculty, and English proficiency level.

A large number of SCMC studies have explored topics related to L2 learning in general, and speaking skills in particular. However, to the best of the current researcher's knowledge, no single study has previously reported on EFL students' attitudes towards English accents. Furthermore, almost all existing studies concerning students' attitudes have relied heavily on students' judgments of their own language gains rather than on learner speaking recordings (Young \& West, 2018). This current study therefore aims to bridge this gap by analyzing recorded speech in order to establish students' interaction with NES and recognize the topics employed during such interaction.

\section{Purpose of Study and Research Questions}

The advent of SCMC tools has enabled EFL learners to interact and communicate with NES with little, or no, cost. Furthermore, SCMC allows EFL learners to practice language outside the classroom, in authentic situations, easily exposing them to different English accents and cultures. However, Buckingham (2014) pointed out that "EFL learners often still consider inner circle Native English Speakers (NES) pronunciation as their learning goal" (p. 1). Therefore, the participants in this study were asked to use synchronous CMC websites to communicate with native English speakers, in order to establish how Saudi students use SCMC platforms and their attitudes towards American and British accents.

The study was guided by the following questions: 
1) Which English accents do Saudi university students tend to prefer, and why?

2) What are the most topics Saudi students most frequently choose when conversing with native English speakers?

3) Do Saudi students find talking to native English speakers interesting?

4) What are students' attitudes towards web-based speaking platforms?

\section{Methodology}

\subsection{Participants}

The main participants in this study were all Saudi native Arabic-speaking males with an average age of 20 years and different average time of studying English (Table 1). All participants except one student, who lived in the US with his parents when he was a kid, did not have a chance to contact with NES or discover English culture. Participants were enrolled in a compulsory Computer Assisted Language Learning (CALL) course designed for sophomore students studying at the English and translation department at an urban public Saudi university. The main objective of this study was to facilitate students in developing and articulating different usages of computers for improving their language skills. In addition, it directs students to current research and trends related to technology and language teaching and learning.

Table 1. The average years of learning English

\begin{tabular}{ll}
\hline Years of Learning English & Participants \\
\hline $1-3$ & 22 \\
$4-6$ & 9 \\
$7-10$ & 4 \\
More than 10 & 5 \\
\hline
\end{tabular}

\subsection{Research Design}

There is a growing tendency for studies to use a mixed-methods approach in applied linguistics research (Dörnyei, 2007), i.e., "a procedure for collecting, analyzing, and mixing quantitative and qualitative data at some stage of the research process within a single study to understand a research problem more completely" (Creswell, as cited in Ivankova \& Creswell, 2009, p. 137). The current researcher therefore employed a mixed-methods approach combining both quantitative and qualitative methods, in order to obtain as much information as possible, as well as establish complete answers to the research questions concerning interaction with inner-circle Native English Speakers (NES).

\subsection{Cambly as a SCMC Platform}

From the outset of the Internet, various SCMC platforms have emerged and allowed language learners to interact with NES in a straightforward manner. However, it remains a challenging process to connect English language learners with competent English-speaking conversation partners (Terhune, 2016). Cambly is a commercial company founded in 2013, focusing on assisting English language learners to practice speaking skills with qualified native (or native-like) tutors. Although all platforms afford opportunities for students to interact with native speakers, Cambly is unique in that it offers an educational service unavailable on other web-based platforms. The main mission of the company is to link English teachers with ESL/EFL learners around the world, with its success being due to the simplicity of the web-based interface and the availability of downloadable applications. Thus, a simple button click allows learners the opportunity to speak with NES at any time they choose. In addition, prior to selecting an interlocutor, students can browse a wide range of educational and professional profiles of English tutors and read about their teaching experience and interests. The platform also facilities the choice of interesting topics to read about and then discuss with tutors.

\subsection{Instruments}

It has been previously argued that the mixing (or blending) of data provides a more effective understanding of questions than the use of a single approach (Creswell, 2014). Therefore, 3 main instruments were used to collect data for this study. Firstly, this research employed a web-based attitudinal questionnaire (see Appendix A) to explore students' behavior when using SCMC platforms. Secondly, students answered 3 open-ended questions encouraging them to openly and freely express their thoughts and ideas (see Appendix B). Thirdly, the students engaged in half-hour recorded conversations with both American and British speakers. In order to cross-validate 
the answers, the data were analyzed both quantitatively and qualitatively.

\section{Results}

This section presents the key findings of the study in relation to the research questions highlighted above. A number of items in the survey have been grouped and linked to the designated research question, with the aim of ensuring the presentation of the findings is both simple and understandable. The online survey used a 5-Likert-point scale. However, for the purposes of clarity in this discussion both (strongly agree, and agree) and (disagree and strongly disagree) have been combined. In addition, both the quantitative and qualitative analysis are brought together in the first three questions, in order to cross-validate the findings and obtain a deeper understanding of the issue.

\section{Research Question 1: Which English accents do Saudi university students tend to prefer, and why?}

The main objective of this research paper was to explore students' potential preference for either the American or British accent, as 2 varieties of the inner circle of the concentric circles proposed by Kashru (1997). In addition, it sought to establish the reasons behind such preferences, based on real conversations with both American and British speakers using an SCMC website. In order to obtain a clear answer to the above question, students were first asked if they were able to easily distinguish between the two accents (see Figure 1).

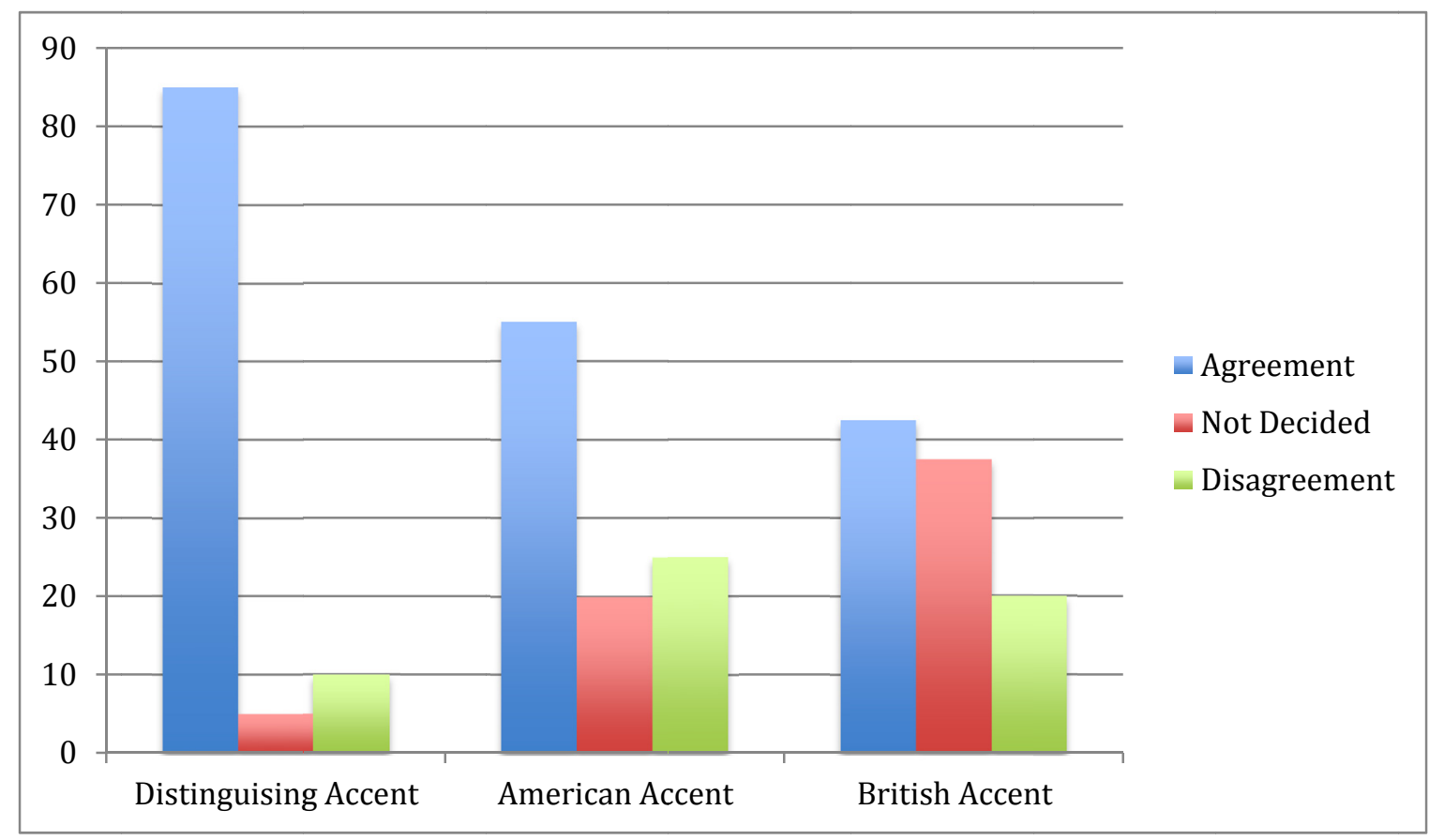

Figure 1. Distinguishing between accents

Figure 1 reveals that $85 \%$ of the students agreed that they experienced no difficulties in recognizing both accents and distinguishing between the two. This was a crucial fact to establish before exploring student's preferences.

Two direct questions in the survey focused on eliciting students' preferences for American and British accents. The results revealed that students generally favored the American accent, with $55 \%$ of students preferring the American accent and approximately $43 \%$ preferring the British accent (Figure 1). In order to cross-validate the survey results, students were given an open-ended question exploring preferences, while at the same time recognizing the reasons for their preferred accent. After analyzing the students' responses, the researcher identified 3 main reasons: (1) previous exposure to the accent: several students confirmed that their exposure to American movies had ensured the American accent was easier to understand, with one stating: "(I prefer the) American accent, because I am used to it I guess, I hear it all the time in movies." Another student noted: "[I prefer American], because [I] used to listen and watch movies in this accent." This finding accords with previous studies in EFL contexts (e.g., Chiba, Matsuura, \& Yamamoto, 1995; Fang, 2016), but contradicts various other studies (e.g., Bernaisch \& Koch, 2016; Buckingham, 2014). (2) The pronunciation of words: this was deemed 
important, as it made the conversation comprehensible. One student said: "I like the American accent, because it was easy to pronounce and hear." This was confirmed by a further student stating: "actually, [I] found American more likeable, because it is easier and sounds very understandable." While another student stated: "I like The American, because the way that she [pronounces] the words is clear." (3) Personal choice: one student said, "I absolutely prefer the American accent, it's the one [I'm] used to speaking since [I] was a kid," while a second confirmed that he liked American accent "because this is the accent that I am learning."

Less than half of the participants stated a preference for the British accent, due to either personal preferences or issues surrounding pronunciation. One student expressed his personal attitude towards the British accent as follows: "actually, I like the British accent because it makes you seem like a gentleman and you think you are an influential speaker." Another confirmed: "I prefer the British one, because I am a big fan of it and it sounds beautiful to me." While a third noted: "honestly, [I] like the British accent because [I] was already familiar with the American accent but the British accent was a new wonderful experience to me."

Many students explicitly stated that they were attracted to the British accent. One student responded: “(I) definitely prefer the British accent, due to its formality, which makes it very likable." Another student replied: "I like them both, but I like the British accent more because it has a special tone." While a further student stated: "I like the British accent more because it's unique and the pronunciation of the words is so cool."

Research question 2: What are the most topics Saudi students most frequently choose when conversing with native English speakers?

In addition to exploring students' preferences when it came to English accents, the study investigated in depth the type of topics chosen and which of the interlocutors took the initiative and picked the topic (or topics) of conversation. The analysis of students' recorded conversations (as well as their responses to an open-ended question about the topic) is summarized in Table 2, below.

Table 2. Topics of conversation

\begin{tabular}{ll}
\hline Topic & Frequency \\
\hline Languages & 21 \\
Sport & 10 \\
Weather & 8 \\
Movies/TV shows & 8 \\
Culture & 8 \\
College/university & 5 \\
Life style & 5 \\
Food & 4 \\
Travel & 4 \\
General (not specified) topics & 4 \\
Future plans & 3 \\
Weight loss/bodybuilding & 3 \\
Games & 3 \\
Transportation & 2 \\
Religion & 1 \\
\hline
\end{tabular}

Table 2 reveals that the most frequently discussed topic with NES consisted of issues related to language, while the least discussed was religion. It can be argued that, because all participants were English majors, it was highly probably that they would discuss the field of their major with their English interlocutors. In addition, several recordings showed that tutors on the SCMC website asked students about their major and their reasons for specializing in English. This therefore explains the popularity of discussions about languages in many conversations. There was only one occasion on which religion was discussed. It is worth noting that discussion of religious issues with intermediate-level students was not expected, as the main objective of the SCMC website relates to issues concerning the English language. More importantly, many of the students considered religion to be too sensitive and difficult topic to discuss, regardless of their level of English proficiency.

Interestingly, the data revealed that (as shown in Figure 2, below), when discussing different topics with NES, the students negotiated meaning and achieved the goals of their conversation. In addition, they also tended to take the initiative and select the subject of the conversation, which is not always the case in classroom discussions. Figure 2 demonstrates that approximately $70 \%$ of students confirmed that they voluntarily chose the 
topic(s) of conversation compared to $30 \%$ of their native English interlocutors. This indicates that students were freed from anxiety and fulfilled the task without any hesitation, supporting Machmud and Abdulah's (2017) assertion that the use of technology (i.e., smartphones) during speaking classes minimizes students' anxiety in relation to peer pressure.

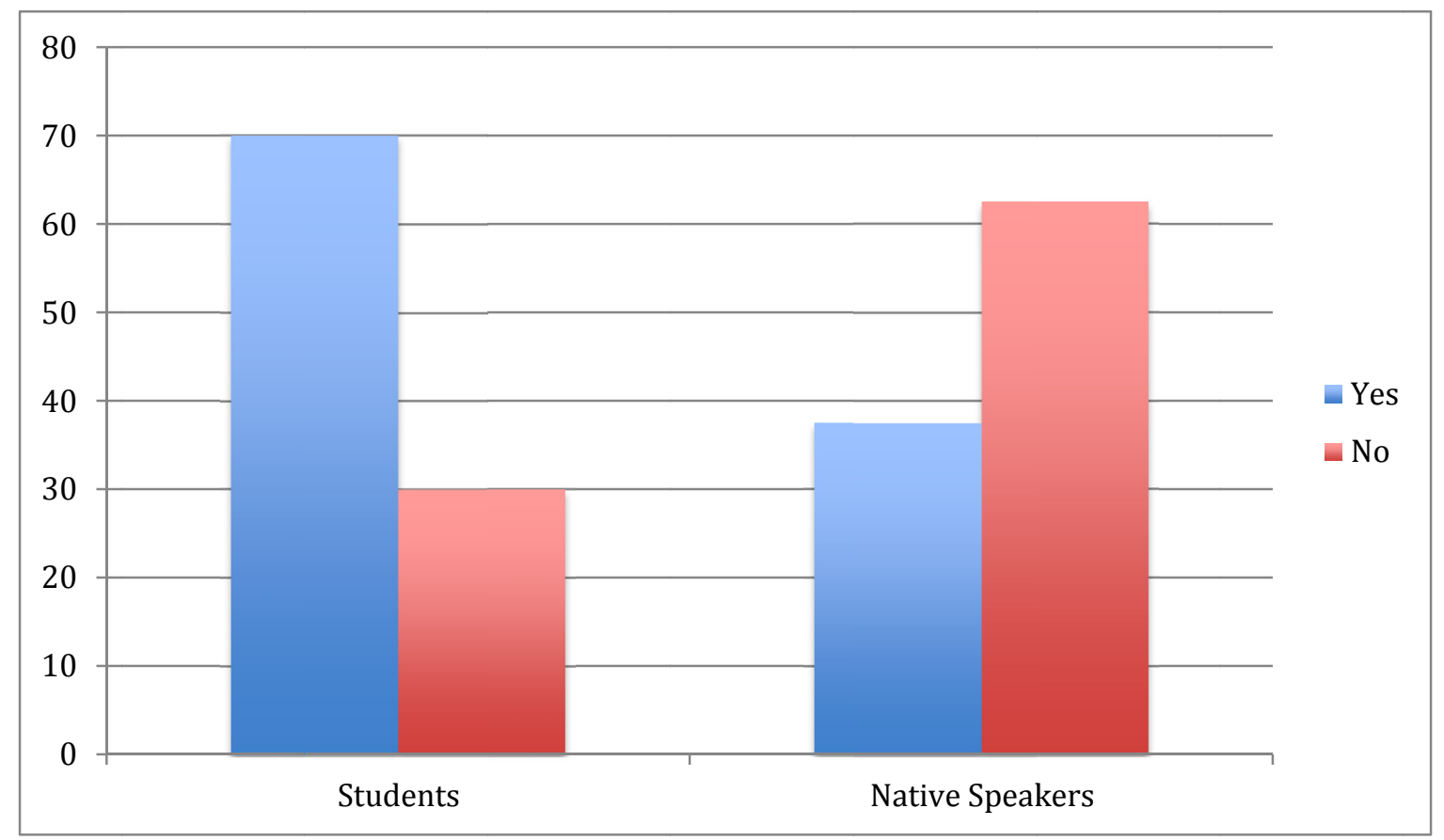

Figure 2. Choosing topic(s) of conversation

\section{Research question 3: Do students find talking to native English speakers interesting and why?}

To answer this question, the students were asked whether they had enjoyed the conversation and also to provide reasons. The data revealed that 39 out of the 40 students stated that they found talking with both the American and British speakers interesting. For example, one student confirmed that speaking with NES is a great opportunity in the EFL context: "actually it was, because I don't get to talk with native speakers very often here in Saudi Arabia." Another student stated that talking with native English speakers had increased his confidence: "yes I found it interesting, because it gave me confidence when it came to speaking myself." Thus, it can be seen that conversing with native English speakers helps students improve both their confidence and interaction, and use the language in authentic situations. One student confirmed this by saying: "certainly yes, because it's very helpful to speak with a native speaker to improve your interaction and use of the English language." The variety of subjects discussed is a further indirect indicator demonstrating that students were interested in the real conversations (see Table 2, above).

Research question 4: What are students' attitudes towards web-based speaking platforms?

As noted previously, the advent of different SCMC websites has facilitated EFL learners to locate NES with whom to practice English. However, not all websites can be assumed to grant speaking and communication skills. As noted above, this current study explores Saudi students' attitudes towards a specific website, i.e., Cambly. Figure 3 demonstrates that $95 \%$ of the students in this research reported the website was easy to navigate, despite over half the participants being unfamiliar with Cambly. The data also revealed that approximately $86 \%$ of students confirmed that Cambly opened new opportunities for conversing with NES in an entertaining and interesting manner. More significantly, $95 \%$ of students confirmed that Cambly was both an effective platform for speaking with native English speakers and it also assisted them in improving their own speaking skills. 


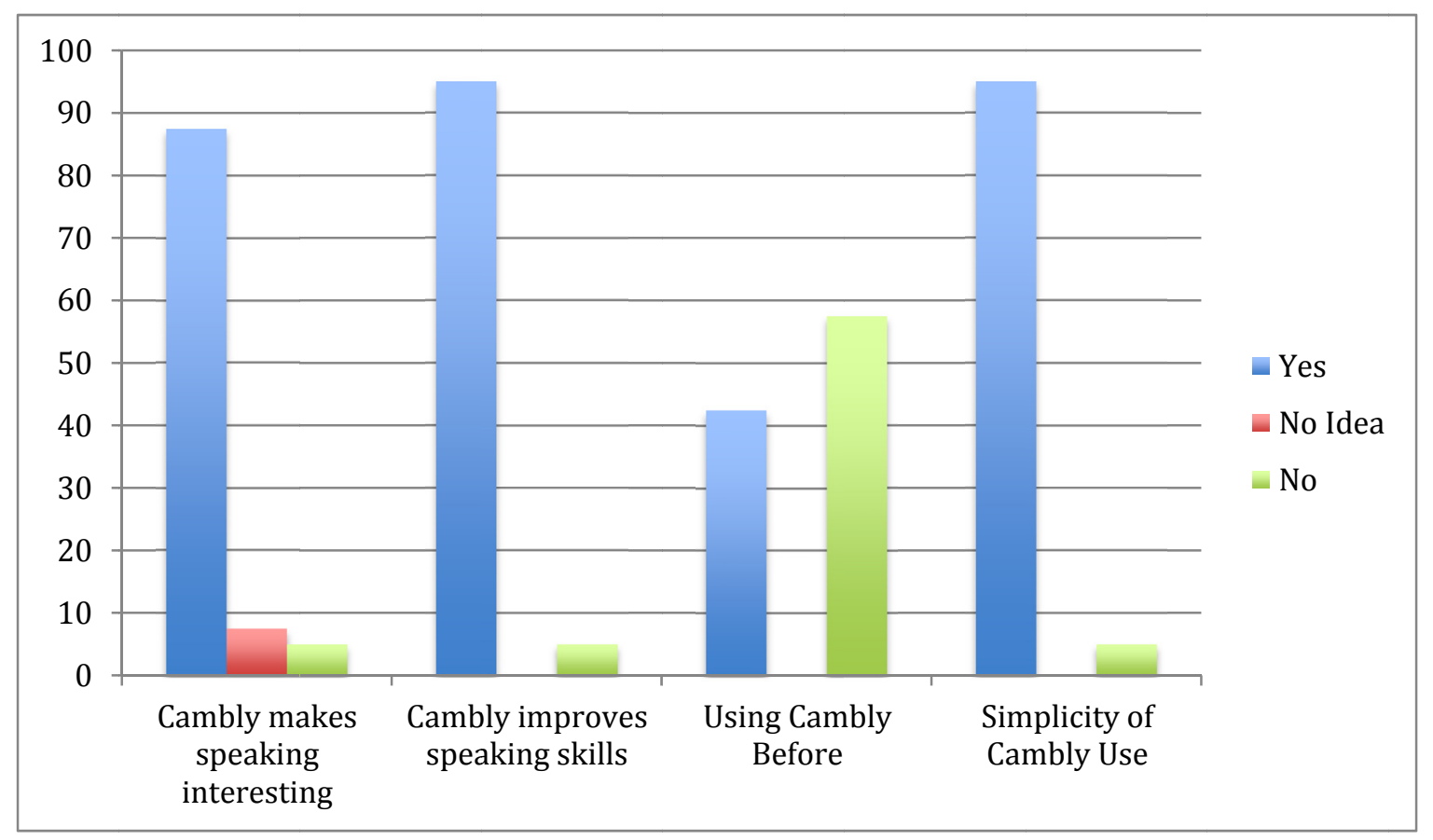

Figure 3. Students' attitudes towards Cambly

\section{Discussion}

This section discusses and interprets the major findings of the study presented above. To begin with the students' preference to either American or British accents, the data show that 22 students (55\%) prefer American English variety to British English with 18 students (43\%). Because the sample of the study is relatively small which shows about $12 \%$ difference, there is no statistical significance in accent preference. This inference is based on the students' open statements about American and British accents and the various reasons behind preference for each accent as mentioned above. The small preference gap implicitly indicates that students consider English as International Language (EIL) which places the importance on communication rather than the English accent. This is totally confirmed by Derwing and Munro (1997) who assure there is no link between intelligibility and accentedness. The number and variety of conversation topics (Table 2 above) indicate that students are extrinsically motivated as they negotiate meaning and exchange ideas in lengthy talks which is not the case in face-to-face speaking classes. Situated SCMC within the interaction hypothesis, Ziegler (2016) argues that SCMC platforms provide opportunities for interaction and negotiation of meaning. The current study proves that utilizing SCMC in speaking classes fosters students speaking skills and increases intrinsic motivation, which is not achievable in the classroom speaking activities (e.g., Alrabai, 2014; Alrashidi \& Phan, 2015; Al-Seghayer, 2014).

The recorded conversations, a feature embedded in the Cambly platform, reveal that students take the initiatives and pick the topic(s) of conversation themselves. By doing so, not only students feel comfortable and confident in conversing with NES, but also, they are scaffolded by a more competent speaker i.e. NES in a sociocultural environment. In other words, the concept of zone of proximal development (ZPD), which comes under the umbrella of SCT, is clearly noticeable. Proposing that learning takes place through social interaction in learners' ZPD, Vygotsky (1978) described the ZPD as "the distance between the actual development level as determined by independent problem solving and the level of potential development as determined through problem solving under adult guidance or in collaboration with more capable peers" (p. 86). SCMC speaking platforms shorten the imaginary distance between NES and language learners because applying scaffolding techniques has great effect on the development of speaking ability for EFL students (Alwahibee, 2019); however, it is not taken for granted that all SCMC platforms permit students to connect with competent English-speaking conversation partners (Terhune, 2016). Worth noting that the SCMC used in this study-Cambly-is a unique platform because it is mainly designed for all language learners to practice speaking skills with native or native-like qualified English tutors. 


\section{Pedagogical Implications}

This study presents several pedagogical and methodological implications for both language instructors and language learners. SCMC platforms not only allow learners to find NES easily, but also to have conversations, exchange ideas, and negotiate meaning in a friendly atmosphere. Students also get immediate feedback on the use of the English language, e.g. pronunciation, and word choice from English interlocutors. Lin (2014) confirms the affordances of SCMC by stating "features of CMC seem to provide opportunities to create a social interaction context with more flexibility that cannot be afforded in a traditional face-to-face environment" (p. 262).

Pedagogically speaking, SCMC platforms help language instructors to modify teaching methods and address students' challenges based on their preferences to accents and preferable topics to achieve communication. More specifically, SCMC speaking platforms open new avenues for speaking language instructors to check students' real and authentic conversations via recorded videos, which assist instructors not only to assess students' speaking skills, but also to recognize how students converse with native English speakers in real situations which are difficult to achieve in the Saudi context. Alharbi (2015) assured that an absence of authentic language learning results in inadequate oral skills among Saudi students.

\section{Conclusion}

The purpose of this paper is to explore Saudi students' attitudes and practices while using a synchronous CMC website known as Cambly, which proved an encouraging location for students to practice the speaking of English. The findings are in line with those of previous studies (i.e., Kessler, 2007; Machmud, 2017) that technology facilitates the learning process during language teaching, particularly in EFL contexts in which NES are difficult to access. SCMC therefore provides a new arena for language learners to foster L2 speaking practice (Blake, 2016). The paper also proves that the goal of mutual intelligibility and expanding a comprehensive understanding of accent varieties is more significant than blindly following a single model for pronunciation instruction (Khatib \& Monfared, 2017).

To conclude, the findings of this study cannot be generalized in relation to all EFL students or all English proficiency levels. This is due to the following aspects: firstly, all the participants were male; secondly, the conversations took place over a limited time; and thirdly, the participants only held conversations with one American and one British speaker. This study therefore recommends the need to also explore the attitudes of female students and investigate the practices of advanced students when using Cambly. In addition, it recommends exposing Saudi students to different English varieties of the inner circle, including their practices, i.e., New Zealand, Canada and Australia. Finally, a comparison between various web-based speaking platforms would enable improved understanding of the efficacy of such tools on speaking performance.

\section{Acknowledgment}

The Author extends his appreciation to the Cambly Inc. company for giving free 30 minutes codes to carry out this study.

\section{References}

Abrams, Z. I. (2003). The effect of synchronous and asynchronous CMC on oral performance in German. The Modern Language Journal, 87(2), 157-167. https://doi.org/10.1111/1540-4781.00184

AbuSeileek, A. F. (2007). Cooperative vs. individual learning of oral skills in a CALL environment. Computer Assisted Language Learning, 20(5), 493-514. https://doi.org/10.1080/09588220701746054

Al-Seghayer, K. (2014). The four most common constraints affecting English teaching in Saudi Arabia. International Journal of English Linguistics, 4(5), 17. https://doi.org/10.5539/ijel.v4n5p17

Alharbi, H. A. (2015). Improving Students' English-Speaking Proficiency in Saudi Public Schools. International Journal of Instruction, 8(1), 105-116. https://doi.org/10.12973/iji.2015.818a

Alrabai, F. (2014). A model of foreign language anxiety in the Saudi EFL context. English Language Teaching, 7(7), 82-101. https://doi.org/10.5539/elt.v7n7p82

Alrashidi, O., \& Phan, H. (2015). Education context and English teaching and learning in the kingdom of Saudi Arabia: An overview. English Language Teaching, 8(5), 33-44. https://doi.org/10.5539/elt.v8n5p33

Alwahibee, K. M. (2019). The Impact of Scaffolding Techniques on Saudi English-Language Learners' Speaking Abilities. International Journal of English Linguistics, 9(5), 37. https://doi.org/10.5539/ijel.v9n5p37 
Beatty, K. (2003). Teaching and researching: Computer-assisted language learning. London, England: Routledge.

Bernaisch, T., \& Koch, C. (2016). Attitudes towards Englishes in India. World Englishes, 35(1), 118-132. https://doi.org/10.1111/weng.12174

Bilbatua, L., Saito, R., \& Bissoonauth-Bedford, A. (2012). Using skype technology to enhance spoken language skills: Preliminary results from a pilot study in French, Japanese and Spanish at the university of Wollongong (pp. 548-556). Paper presented at the EDULearn12 Proceedings. 4th International Conference on Education and New Learning Technologies IATED, Spain.

Blake, C. (2009). Potential of text - based internet chats for improving oral fluency in a second language. The Modern Language Journal, 93(2), 227-240. https://doi.org/10.1111/j.1540-4781.2009.00858.x

Blake, R. (2016). Technology and the four skills. Language Learning and Technology, 20(2), 129-142.

Blake, R., Wilson, N. L., Cetto, M., \& Pardo-Ballester, C. (2008). Measuring oral proficiency in distance, face-to-face, and blended classrooms. Language Learning and Technology, 12(3), 114.

Buckingham, L. (2014). Attitudes to English teachers' accents in the Gulf. International Journal of Applied Linguistics, 24(1), 50-73. https://doi.org/10.1111/ijal.12058

Chang, Y. (2007). The potential of synchronous text-based computer-mediated communication for second language acquisition. Issues in Information Systems, 8(2), 355-361.

Chiba, R., Matsuura, H., \& Yamamoto, A. (1995). Japanese attitudes toward English accents. World Englishes, 14(1), 77-86. https://doi.org/10.1111/j.1467-971X.1995.tb00341.x

Creswell, J. W. (2014). Research design: Qualitative, quantitative, and mixed methods approaches. Thousand Oaks, CA: SAGE.

Derwing, T. M., \& Munro, M. J. (1997). Accent, intelligibility, and comprehensibility: Evidence from four L1s. Studies in Second Language Acquisition, 19, 1-16. https://doi.org/10.1017/S0272263197001010

Dörnyei, Z. (2007). Research methods in applied linguistics: Quantitative, qualitative, and mixed methodologies. Oxford: Oxford University Press.

Fang, F. G. (2016). Investigating attitudes towards English accents from an ELF framework. The Asian Journal of Applied Linguistics, 3(1), 68-80.

Fernández-García, M., \& Martínez-Arbelaiz, A. (2002). Negotiation of meaning in nonnative speaker-nonnative speaker synchronous discussions. Calico Journal, 279-294. https://doi.org/10.1558/cj.v19i2.279-284

Hamad, M. M. (2013). Factors negatively affect speaking skills at Saudi colleges for girls in the south. English Language Teaching, 6(12), 87-97. https://doi.org/10.5539/elt.v6n12p87

Huang, H. D., \& Hung, S. A. (2010). Effects of electronic portfolios on EFL oral performance. Asian EFL Journal, 12(2), 192-212.

Ivankova, N. V., \& Creswell, J. W. (2009). Mixed methods. Qualitative Research in Applied Linguistics: A Practical Introduction, 135-161. https://doi.org/10.1057/9780230239517_7

Kachru, B. B. (1997). World Englishes and English-using communities. Annual Review of Applied Linguistics, 17, 66-87. https://doi.org/10.1017/S0267190500003287

Kessler, G. (2007). Formal and informal CALL preparation and teacher attitude toward technology. Computer Assisted Language Learning, 20(2), 173-188. https://doi.org/10.1080/09588220701331394

Khatib, M., \& Monfared, A. (2017). Exploring English Teachers' attitudes towards Pronunciation issues and varieties of English in three circles of world Englishes. Applied Research on English Language, 6(2), 213236.

Lai, C., \& Zhao, Y. (2006). Noticing and text-based chat. Language Learning and Technology, 10(3), 102-120.

Lin, H. (2014). Computer-mediated communication (CMC) in L2 oral proficiency development: A meta-analysis. Recall, 27(3), 261-287. https://doi.org/10.1017/S095834401400041X

Loewen, S., \& Erlam, R. (2006). Corrective feedback in the chatroom: An experimental study. Computer Assisted Language Learning, 19(1), 1-14. https://doi.org/10.1080/09588220600803311

Long, M. H. (1983). Native speaker/non-native speaker conversation and the negotiation of comprehensible input. Applied Linguistics, 4(2), 126-141. https://doi.org/10.1093/applin/4.2.126 
Lord, G. (2008). Podcasting communities and second language pronunciation. Foreign Language Annals, 41(2), 364-379. https://doi.org/10.1111/j.1944-9720.2008.tb03297.x

Machmud, K. (2017). Technology-integrated ESP (English for specific purposes) instructions: The engineering students' perspectives. The Asian EFL Journal, 8(1), 67-72.

Machmud, K., \& Abdulah, R. (2017). Using smartphone-integrated model of teaching to overcome students' speaking anxiety in learning English as a foreign language. Journal of Arts and Humanities, 6(9), 01-11. https://doi.org/10.18533/journal.v6i9.1249

Mahboob, A., \& Elyas, T. (2014). English in the kingdom of Saudi Arabia. World Englishes, 33(1), 128-142. https://doi.org/10.1111/weng.12073

Mahfouz, S. M., \& Ihmeideh, F. M. (2009). Attitudes of Jordanian university students towards using online chat discourse with native speakers of English for improving their language proficiency. Computer Assisted Language Learning, 22(3), 207-227. https://doi.org/10.1080/09588220902920151

Payne, J. S., \& Whitney, P. J. (2002). Developing L2 oral proficiency through synchronous CMC: Output, working memory, and interlanguage development. CALICO Journal, 7-32. https://doi.org/10.1558/cj.v20i1.7-32

Sanders, R. F. (2005). Redesigning introductory Spanish: Increased enrollment, online management, cost reduction, and effects on student learning. Foreign Language Annals, 38(4), 523-532. https://doi.org/10.1111/j.1944-9720.2005.tb02519.x

Satar, H. M., \& Özdener, N. (2008). The effects of synchronous CMC on speaking proficiency and anxiety: Text versus voice chat. The Modern Language Journal, 92(4), 595-613. https://doi.org/10.1111/j.1540-4781.2008.00789.x

Sun, Y. (2012). Examining the effectiveness of extensive speaking practice via voice blogs in a foreign language learning context. CALICO Journal, 29(3), 494-506. https://doi.org/10.11139/cj.29.3.494-506

Terhune, N. M. (2016). Language learning going global: Linking teachers and learners via commercial skype-based CMC. Computer Assisted Language Learning, 29(6), 1071-1089. https://doi.org/10.1080/09588221.2015.1061020

Tsukamoto, M., Nuspliger, B., \& Senzaki, Y. (2009). Using skype $\odot$ to connect a classroom to the world: Providing students an authentic language experience within the classroom (pp. 5162-5168). Paper presented at the CamTESOL Conference on English Language Teaching: Selected Papers.

Ürün, M. F. (2015). Integration of technology into language teaching: A comparative review study. Journal of Language Teaching and Research, 7(1), 76-87. https://doi.org/10.17507/jltr.0701.09

Volle, L. M. (2005). Analyzing oral skills in voice e-mail and online interviews. Language Learning and Technology, 9(3), 146-163.

Vygotsky, L. S. (1978). Mind in society: The development of higher psychological processes. Cambridge, MA: Harvard University Press.

Warschauer, M. (1996). Comparing face-to-face and electronic discussion in the second language classroom. CALICO Journal, 13(2), 7-26.

Young, E. H., \& West, R. E. (2018). Speaking practice outside the classroom: A literature review of asynchronous multimedia-based oral communication in language learning. The EuroCALL Review, 26(1), 59-78. https://doi.org/10.4995/eurocall.2018.8599

Ziegler, N. (2016). Synchronous computer-mediated communication and interaction: A meta-analysis. Studies in Second Language Acquisition, 38(3), 553-586. https://doi.org/10.1017/S027226311500025X 


\section{Appendix A}

\begin{tabular}{|c|c|c|c|c|c|}
\hline Statement & $\begin{array}{l}\text { Strongly } \\
\text { disagree }\end{array}$ & disagree & $\begin{array}{l}\text { Neither agree } \\
\text { Neither disagree }\end{array}$ & Agree & $\begin{array}{l}\text { Strongly } \\
\text { agree }\end{array}$ \\
\hline \multicolumn{6}{|l|}{ It was easy to use Cambly website. } \\
\hline \multicolumn{6}{|l|}{ Cambly makes English speaking interesting } \\
\hline \multicolumn{6}{|l|}{ Using Cambly improves my speaking skills. } \\
\hline \multicolumn{6}{|l|}{ I prefer American accent } \\
\hline \multicolumn{6}{|l|}{ I prefer British accent } \\
\hline \multicolumn{6}{|l|}{ I understand American speakers easily } \\
\hline \multicolumn{6}{|l|}{ I understand British speakers easily } \\
\hline \multicolumn{6}{|l|}{$\begin{array}{l}\text { I easily distinguish between American accent and British } \\
\text { accent. }\end{array}$} \\
\hline \multicolumn{6}{|l|}{ I used Cambly before. } \\
\hline \multicolumn{6}{|l|}{ I chose the topic of conversation myself. } \\
\hline The English speaker chose the topic of conversation. & & & & & \\
\hline
\end{tabular}

\section{Appendix B}

1) Did you find speaking with a native English speaker interesting? Why?

2) What was the topic you talked about?

3) Did you like the American or British accent? Why?

\section{Copyrights}

Copyright for this article is retained by the author, with first publication rights granted to the journal.

This is an open-access article distributed under the terms and conditions of the Creative Commons Attribution license (http://creativecommons.org/licenses/by/4.0/). 